\title{
KEWENANGAN PENGADILAN AGAMA DALAM MEMUTUS PEMBATALAN AKTA HIBAH (ANALISIS PUTUSAN MAHKAMAH AGUNG NOMOR : 78 PK/Ag/2013)
}

\author{
Annisa Setyo Hardianti \\ Program Studi Magister Kenotariatan \\ Pascasarjana Fakultas Hukum Universitas Brawijaya \\ Jalan MT. Haryono 169 Malang 65145, Telp/Fax: (0341) 553898/566505 \\ Email : setyo.annisa@yahoo.com
}

\begin{abstract}
The general understanding of grant is an act included in a legal action in which a transfer of ownership rights are intentionally transferred to those or others. The grants under civil law stipulated in the Law of Civil Law or Burgelijk Wetboek (BW) in Article 1666 to Article 1693, whereas in Islamic law grants stipulated in Islamic Law Compilation (KHI) from Article 210 to Article 214. The Principal Problems in Cancellation Deed of Grant numbers: 162 / KLJ / 11/1999, where there was a mistake of judgment on the first and second claims is that the Religious Court had no authority to decide the case of cancellation deed grants whereas there are already rules which clearly stipulates that the Religious Court authorized in deciding the case among Muslims in Article 3 and Article 49 of Law No. 3 of 2006 which has been updated to Law Number 50 Year 2009 on Religious Courts. To the level of Final Appeal and Review of judgment turned into the Religious Court in charge of the case of cancellation of the Grant Deed. The objectives to be achieved through this research is to analyze the Supreme Court ruling number: $78 \mathrm{PK} / \mathrm{Ag} / 2013$ and all processes so that there is an error the same for judges who would decide a similar case. The study was conducted using the method of juridical normative approach law (statute approach) and the approach to the concept (conceptual approach) which is then analyzed by using prescript. Judge's decision that deviates from the rules of law regarding the authority of the Religious Court may result in an injustice and not achieving legal certainty, while the state has been set up very clearly in the Act.
\end{abstract}

Keywords: Jurisdiction of Religious Court, Grant Deed Cancelation, Court Judgment.

\begin{abstract}
Abstrak
Pengertian hibah secara umum yaitu hibah termasuk dalam perbuatan hukum dimana terjadi pemindahan hak kepemilikan yang sengaja untuk dialihkan kepada pihak atau orang lain. Adapun hibah menurut hukum perdata diatur dalam Kitab Undang-undang Hukum Perdata atau Burgelijk Wetboek (BW) dalam Pasal 1666 sampai dengan Pasal 1693, sedangkan dalam hukum Islam hibah diatur dalam Kompilasi Hukum Islam (KHI) mulai dari Pasal 210 hingga Pasal 214. Dalam Pokok Permasalahan pembatalan Akta Hibah nomor : 162/Klj/11/1999, dimana terjadi suatu kesalahan yaitu putusan pada tingkat pertama dan kedua menyatakan bahwa Pengadilan Agama tidak berwenang untuk memutus perkara pembatalan Akta Hibah tersebut sedangkan sudah ada aturan yang dengan jelas mengatur bahwa Pengadilan Agama berwenang dalam memutus perkara diantara umat Islam atau muslim dalam Pasal 3 dan Pasal 49 Undang-Undang Nomor 3 Tahun 2006 yang telah diperbarui menjadi Undang-Undang Nomor 50 Tahun 2009 tentang Peradilan Agama. Hingga pada tingkat Kasasi dan Peninjauan Kembali putusan berubah menjadi Pengadilan Agama berwenang atas perkara pembatalan Akata Hibah tersebut. Adapun tujuan yang ingin dicapai melalui penelitian ini adalah untuk menganilisis putusan Mahkamah Agung nomor : 78 PK/Ag/2013 beserta segala proses sehingga tidak terjadi suatu kesalahan yang sama bagi para hakim yang kelak memutus perkara serupa. Penelitian dilakukan menggunakan metode yuridis normatif dengan metode pendekatan perundang-undangan (statute approach) dan pendekatan konsep (conceptual
\end{abstract}


approach) yang kemudian dianalisis dengan menggunakan teknik preskripif. Putusan Hakim yang menyimpang dari aturan perundang-undangan mengenai kewenangan Pengadilan Agama mengakibatkan terjadinya suatu ketidakadilan dan tidak tercapainya suatu kepastian hukum, sedangkan negara telah mengatur dengan sangatjelas dalam Undang-undang.

Kata Kunci : Kewenangan Pengadilan Agama, Pembatalan Akta Hibah, Putusan Pengadilan.

\section{A. Pendahuluan}

Lingkup hukum perdatapun beraneka ragam, mulai dari perikatan, perkawinan, perjanjian, dan masih banyak hal lagi. Pembahasan kali ini difokuskan pada permasalahan hukum perdata perihal hibah. Pengertian hibah juga beragam, di sesuaikan dengan contoh kasus yang sedang dianalisa.

Pengertian hibah secara umum yaitu hibah termasuk dalam perbuatan hukum dimana terjadi pemindahan hak kepemilikan yang sengaja untuk dialihkan kepada pihak atau orang lain. Pemindahan hak dilakukan pada saat pemegang hak atas objek hibah tersebut masih hidup dan merupakan suatu perbuatan hukum yang bersifat tunai, kecuali pada hibah wasiat. Ada banyak bentuk perbuatan hukum dalam persoalan pemindahan hak yang dapat dilakukan dengan cara hibah, diantaranya jual beli, tukar menukar, pemberian menurut adat, pemasukan dalam perusahaan (inbreng) dan hibah wasiat (legaat) (Boedi Harsono, 2003).

Selain itu, hibah juga dapat dijadikan sebagai salah satu solusi dalam menyelesaikan suatu masalah waris. Namun dilain sisi, dalam fakta masyarakat pemberian hibah juga dapat menimbulkan permasalahan-permasalahan, sehingga tujuan hibah yang sebenarnya tidak sejalan sebagaimana mestinya. Penyelesaian jika terjadi sengketa mengenai obyek hibah terpaksa harus diselesaikan di pengadilan.

Hibah seringkali disamakan dengan peristiwa waris, padahal apabila dianalisa jauh lebih dalam maka akan diketahui bahwa hibah berbeda dengan waris. Hibah terjadi pada saat si pemberi hibah masih hidup selama waktu pelaksanaan pemberian hibat tersebut, sedangkan apabila dalam waris akan terjadi pada saat seseorang telah meninggal dunia dengan meninggalkan harta kekayaan atau hal-hal yang dapat diwariskan. Obyek dari pemberian hibah hanya dapat dilakukan pada segala benda yang sudah ada, apabila pemberian atau penyerahan hibah dilakukan pada benda yang baru akan ada dikemudian hari, maka hibah akan menjadi batal (R. Subekti,1995).

Obyek hibah dapat berupa benda-benda bergerak maupun benda-benda tidak bergerak. Dalam tesis ini Penulis membahas mengenai hibah yang obyeknya benda tidak bergerak yaitu tanah dan bangunan. Berdasar pada putusan Mahkamah Agung Nomor : 78 PK/ Ag / 2013 dengan penggugat I dan Penggugat II adalah H. Achmad Jakoen Tjokrohadi bersama istri, sedangkan tergugat I dan Tergugat II adalah Dra. Ani Hadi Setyowati yang berstatus sebagai anak dari Penggugat bersama dengan suami. permasalahan ini diangkat menjadi suatu isu hukum yang dapat dikaji lebih dalam.

Duduk perkara perdata tentang pembatalan Akta Hibah tersebut berawal pada tahun 11 November 1999, dimana para Penggugat yang sudah berusia lanjut tersebut dengan inisiatif Tergugat I dan Tergugat II diajak ke kantor Notaris dan PPAT Tri Sukmawati Handayani, S.H., untuk menandatangani akta hibah. Bahwa dengan segala keterbatasan para Penggugat yang telah usia lanjut dan telah mengalami banyak penurunan kondisi fisik seperti pendengaran dan penglihatan tidak disadari bahwa itu adalah Akta yang berisi bahwa para Penggugat bersedia untuk menghibahkan tanah beserta bangunan obyek sengketa seluruhnya kepada Tergugat I.

Hal ini terjadi karena atas dasar kepercayaan seorang orangtua terhadap anaknya yang diyakini tidak akan memiliki niat buruk terhadap orangtuanya. Bahwa selanjutnya dengan adanya Akta Hibah Nomor 162/Klj/11/1999, 11 November 1999 dimanfaatkan oleh Tergugat untuk membalik nama atau mengalihkan seluruh hak kepemilikan dari tanah dan banguna tersebut atas nama Tergugat I tersebut.

Berawal dari peristiwa itu para Penggugat 
yang pada akhirnya menyadari penyalahgunaan tersebut para Penggugat menempuh jalur hukum melalui Pengadilan Agama Kota Malang dengan Putusan Nomor : 1000/Pdt.G/2011/PA.Mlg. Dikarenakan hasil dari gugatan tersebut adalah tolak karena dianggap bahwa Pengadilan Agama tidak berwenang dalam memutus perkara hibah tersebut, maka dilakukan Banding oleh Penggugat melalui Pengadilan Tinggi Agama d a 1 a m p u t u s a n o m o r : 48/Pdt.G/2012/PTA.Sby keluar dengan hasil mengabulkan permohonan banding namun menguatkan putusan Pengadilan Agama yang mengungkapkan bahwa Pengadilan Agama tidak berhak untuk mengadili perkara hibah tersebut.

Putusan pada tingkat pertama di Pengadilan Agama kota Malang dirasa tidak sesuai dengan Pasal 49 Undang-undang Nomor 7 Tahun 1989 sebagaimana telah diubah dengan Undang-undang Nomor 3 Tahun 3006, dan perubahan kedua dengan Undang-undang Nomor 50 Tahun 2009 menyebutkan "Pengadilan Agama bertugas dan berwenang menyelesaikan perkaraperkara di tingkat pertama antara orang-orang yang beragama Islam di bidang kewarisan, wasiat dan hibah yang dilakukan berdasarkan hukum Islam", berdasarkan fakta hukum dan Akta Hibah terbukti Pemberi Hibah dan Penerima Hibah beragama Islam.

Maka berlanjut pada tingkat Kasasi di Mahkamah Agung putusan Nomor : 492 $\mathrm{K} / \mathrm{AG} / 2012$ yang mengabulkan gugatan para Penggugat sebagian dengan menyatakan bahwa Akta Hibah Nomor 162/Klj/11/1999 tanggal 11 November 1999 yang di buat oleh PPAT Malang Tri Sukmawati Handayani, S.H., batal demi hukum. Berdasarkan keputusan tersebut maka secara implisit putusan tingkat Kasasi tersebut menyatakan Pengadilan Agama berwenang dalam memutus perkara pembatalan Akta Hibah tersebut.

Hingga berlanjut pada Peninjauan Kembali yang kali ini pemohon peninjauan kembali adalah dari pihak Tergugat I dan pihak Tergugat II, yang hasilnya dikuatkan dengan putusan Mahkamah Agung Nomor : $78 \mathrm{PK} / \mathrm{Ag} / 2013$ dengan hasil menolak permohonan peninjauan kembali dari para
Pemohon Peninjauan Kembali yaitu Dra. Ani Hadi Setyowati. Dikatakan bahwa adanya kesalahan terhadap judex yuris oleh para Tergugat yang tidak dapat dibenarkan oleh Hakim. Sehingga Hakimpun berpendapat bahwa judex yuris atau putusan setingkat Mahkamah Agung sudah tepat dan benar dalam memutus perkara tersebut.

Berdasarkan latar belakang dan runtutan masalah yang telah dijelaskan maka peneliti akan membahas lebih dalam mengenai dasardasar hukum dan permasalahanpermasalahan yang ada berkaitan dengan kewenangan Pengadilan Agama dalam memutus perkara hibah karena seperti yang sudah dijelaskan adanya putusan pada tingkat pertama dan kedua yang menyimpangi aturan Pasal 49 Undang-Undang Nomor 3 Tahun 2006 yang telah diperbarui dengan Undangundang Nomor 50 Tahun 2009, serta dalam perihal pengetahuan tentang aturan-aturan hibah yang sesuai dengan aturan dalam Undang-undang.

Selain itu peneliti juga akan membahas mengenai hibah dari sudut pandang Islam, karena hibah tidak dapat dilepas kan dari Hibah secara Islam, hal ini perlu dibahas secara bersamaan karena hibah tidak hanya ada dalam hukum BW (Burgelijk Wetboek) tetapi juga diatur di dalam Kompilasi Hukum Islam (KHI) sesuai dengan syariat Islam.

Berdasarkan latar belakang yang telah diuraikan, maka dapat dirumuskan permasalahan sebagai berikut :

1. Apakah faktor yang membuat putusan Pengadilan Agama berbeda antara tingkat Gugatan hingga Banding dengan putusan pada tingkat Kasasi hingga Peninjauan Kembali Putusan Mahkamah Agung Nomor : 78 PK/Ag/2013 apabila ditinjau dari aturan Perundang-undangan mengenai Peradilan Agama?

2. Bagaimanakah keabsahan Akta Hibah Nomor : 162/K1j/11/1999 apabila ditinjau dari sudut pandang Kompilasi Hukum Islam?

Untuk mengetahui dan menganalisis kewenangan dari Pengadilan Agama dalam memutus suatu perkara hibah yang dalam koridor pembahasan kali ini adalah perihal pembatalan Akta Hibah, dan sejauh mana 
Pengadilan Agama dapat menindak lanjuti peristiwa perkara hukum tersebut. Sehingga dapat menghasilkan sebuah output berupa pemecahan masalah tersebut.

Teori yang digunakan dalam penelitian ini yaitu adalah yang pertama teori Kewenangan, guna mengkaji mengenai kewenangan yang dimiliki oleh Pengadilan Agama dalam memutus perkara pembatalan Akta Hibah Nomor 162/Klj/11/1999. Lalu yang kedua teori Keadilan, dalam teori ini digunakan untuk mengkaji mengenai keadilan yang ditimbulkan akibat adanya kesalahan dalam memutus perkara pembatalan Akta Hibah tersebut.

Selanjutnya adapula teori tentang kepastian hukum yang digunakan untuk mengkaji tentang adanya kesalahan dalam putusan hakim yang tidak sesuai dengan aturan Perundang-undangan sehing menimbulkan keraguan akan kepastian dalam aturan yang sudah tegas diatur dalam Undang-undang. Pada teori terakhir yang digunakan yaitu teori Pertanggung jawaban hukum ini lebih ditujukan bagi para pihak, setelah Akta Hibah Nomor 162/Klj/11/1999 dinyatakan batal demi hukum tentunya menimbulkan suatu akibat bagi para pihak yang bersangkutan, sehingga perlu adanya pertanggungjawaban dari masing-masing pihak.

Dalam penulisan ini digunakan metode yuridis-normatif, dengan jenis pendekatan udang-undang (statue approach) dan pendekatan konseptual (conceptual approach). Melalui metode tersebut maka dapat diketahui bahwa cara pandang hakim dari sudut pandang suatu kasus dapat membuat suatu putusan Pengadilan tidak sesuai dengan aturan yang ada dalam sebuah perundang-undangan. Putusan Hakim yang menyimpang dari aturan perundangundangan mengenai kewenangan dari Pengadilan Agama dapat berakibat terjadinya suatu ketidakadilan dan tidak tercapainya suatu kepastian hukum, sedangkan negara telah mengatur dengan sangat jelas dalam Undang-undang (Abdulkadir Muhammad, 2004).

Dalam penelitian hukum tidak dikenal adanya data, sebab dalam penelitian hukum khususnya yuridis normatif sumber penelitian hukum diperoleh dari kepustakaan bukan dari lapangan, untuk itu istilah yang dikenal adalah bahan hukum (Peter Mahmud Marzuki, 2011).

Bahan hukum primer merupakan bahan hukum yang memiliki sifat autoratif yang artinya memiliki sebuah otoritas. Ada pula bahan hukum primer, yaitu:

a) Undang-undang Dasar Republik 1945.

b) Pasal 1666 hingga Pasal 1693 Kitab Undang-undang Hukum Perdata.

c) Pasal 210 hingga Pasal 214 Kompilasi Hukum Islam.

d) Undang-undang Nomor 50 Tahun 2009 Tentang Peradilan Agama (Lembaran Negara Republik Indonesia Tahun 2009, Tambahan Lembaran Negara Republik Indonesia Nomor 5078).

e) Putusan Mahkamah Agung nomor 78 $\mathrm{PK} / \mathrm{Ag} / 2013$.

Sehingga dapat disimpulkan suatu pelaksanaan hukum tidak cukup hanya dengan suatu aturan yang yang telah mengatur sebuah persoalan tertentu, namun kemampuan dan pemahaman seorang Hakim dalam beracara serta pemahaman para pihak akan aturan tersebut juga perlu untuk diperhatikan agar tidak terjadi suatu penyimpang dalam praktek di tengah masyarakat.

\section{Kerangka Teori}

Sesuai aturan dalam Pasal 1 ayat (1) yang mengatakan bahwa Peradilan Agama merupakan peradilan bagi orang-orang yang beragama Islam. UU Nomor 7 Tahun 1989 Tentang Peradilan Agama sebagaimana telah diubah dan ditambah dengan UU Nomor 3 Tahun 2006 dan UU Nomor 50 Tahun 2009, Pasal 2 yang tertulis : "Peradilan Agama merupakan salah satu dari pelaksana kekuasaan kehakiman bagi rakyat beragama Islam yang mencari keadilan mengenai perkara perdata tertentu yang diatur dalam undang-undang ini".

Berdasarkan aturan tersebut, maka dirasa tepat apabila para Penggugat melakukan gugatan melalui Kepaniteraan Pengadilan Agama kota Malang, mengingat fakta mengatakan bahwa kedua belah pihak yaitu Penggugat dan Tergugat merupaka umat muslim, maka tidak ada alasan lain untuk para 
pihak tidak mengikuti aturan syari'at Islam sesuai dengan kepercayaan yang diyakini.

Terlebih dalam pasal 49 Undang-undang nomor 3 tahun 2006 yang kini telah diperbarui dengan Undang-undang nomor 50 tahun 2009 yang mengatakan bahwa Pengadilan agama bertugas dan berwenang memeriksa, memutus, dan menyelesaikan perkara di tingkat pertama antara orang-orang yang beragama Islam di bidang:
a. perkawinan;
b. waris;
c. wasiat;
d. hibah;
e. wakaf;
f. zakat;
g. infaq;
h. shadaqah;
i. dan ekonomi syari'ah.

Namun, dalam putusan pada tingkat pertama atau gugatan yaitu di Pengadilan Agama kota Malang dan pada tingkat Banding di Pengadilan Tinggi Agama kota Surabaya dinyatakan bahwa Pengadilan Agama tidak berwenang untuk memutus perkara pembatalan Akta Hibah tersebut, atas dasar klausula yang ada pada perjanjian Akta Hibah tersebut.

Sedangkan dalam putusan pada tingkat Kasasi hingga Peninjauan Kembali di Mahkamah Agung Pengadilan Agama berwenang untuk memutus karena atas dasar fakta yang menyebutkan bahwa para pihak merupakan seorang muslim.

\section{B. Pembahasan}

1. Faktor yang Membuat Putusan Pengadilan Dapat Berbeda Mengenai Kewenangan Pengadilan Agama

Berdasarkan ulasan awal diatas bahwa pertimbangan Hakim pada tingkat pertama dan pada tingkat Banding di Pengadilan Tinggi Agama kota Surabaya yang mengatakan bahwa Pengadilan Agama tidak berwenang untuk memutus atas dasar klausula Pasal 5 yang terdapat dalam perjanjian Akta Hibah nomor : $162 / \mathrm{Klj} / 11 / 1999$ tersebut yang mengatakan "Kedua belah pihak dalam hal ini dengan segala akibatnya memilih tempat kediaman hukum yang umum dan tidak berubah oada Kantor Kepaniteraan Pengadilan Negeri di
Malang" sebagai dasar Hakim memutus tidak berwenang pada Pengadilan Agama.

Maka perlu disoroti dengan cermat mengenai batasan kriteria sebuah klausa yang dapat dikatakan pantas dalam menjaga sebuah keadilan yang menjadi dasar dari ideologi sebuah hukum. Pada dasarnya setiap orang bebas melakukan perjanjian. Hal ini sebagai realisasi dari asas kebebasan berkontrak. Kebebasan berkontrak pada dasarnya adalah implementasi dari alam pikiran faham individualis.

Asas kebebasan berkontrak pada prinsipnya sebagai sarana hukum yang digunakan subjek hukum untuk memperoleh hak kebendaan dan mengalihkan hak kebendaan demi pemenuhan kebutuhan diri pribadi subjek hukum. Dalam KUHPerdata yang menganut sistem kontinental kebebasan untuk melakukan kontrak dan menentukan isi kontrak dapat dilihat dalam Pasal 1338 ayat (1) KUHPerdata (Abdullah Tri Wahyudi,2004).

Wujud kebebasan berkontrak baru dapat diketahui dalam praktiknya pada saat melakukan perjanjian. Dalam memenuhi kebutuhan manusia, termasuk kebutuhan akan benda ekonomi, peranan perjanjian ini sangat penting karena perjanjian oleh hukum disebutkan sebagai titel untuk memperoleh hak kepemilikan. Asas kebebasan berkontrak menurut hukum perjanjian Indonesia meliputi ruang lingkup sebagai berikut: (Wirjono Projodikoro, 2000)

a. kebebasan untuk membuat atau tidak membuat perjanjian;

b. kebebasan untuk memilih pihak dengan siapa ia ingin membuat perjanjian;

c. kebebasan untuk menentukan atau memilih kausa dari perjanjian yang dibuatnya;

d. kebebasan untuk menentukan objek perjanjian;

e. kebebasan untuk menentukan syaratsyarat suatu perjanjian termasuk kebebasan untuk menerima atau menyimpangi ketentuan undangundang yang bersifat opsional (aanvullend, optional).

Namun, di mata hukum tidak sematamata bebas adalah tanpa sebuah batasan. Pembatasan terhadap asas kebebasan 
berkontrak juga dapat disimpulkan melalui pasal 1338 ayat (3) yang menyatakan bahwa suatu perjanjian hanya dilaksanakan dengan itikad baik. Oleh karena itu para pihak tidak dapat sesuka hati menentukan klausul-klausul yang terdapat dalam perjanjiian tetapi harus didasarkan dan dilaksanakan dengan itikad baik.

Perjanjian yang didasarkan pada itikad buruk mempunyai akibat hukum perjanjian tersebut dapat dibatalkan. Dengan demikian asas kebebasan berkontrak yang terdapat dalam pasal 1338 tidak lagi bersifat absolut, yang berarti dalam keadaan tertentu hakim berwenang melalui tafsiran hukum untuk meneliti dan menilai serta menyatakan bahwa kedudukan para pihak dalam suatu perjanjian berada dalam keadaan yang tidak seimbang sedemikian rupa, sehingga salah satu pihak dianggap tidak bebas untuk menyatakan kehendaknya.

Hal ini sesuai dengan putusan Hakim pada tingkat Kasasi dimana Hakim mengatakan bahwa "Pasal 1338 tersebut tidak dapat diterapkan pada Pasal 5 akta hibah yang dibuat antara para Penggugat dengan Tergugat I karena klausul Pasal 5 akta hibah tersebut bertentangan dengan Pasal 49 Undang-undang Nomor 7 Tahun 1989 sebagaimana yang telah diubah dengan Undang-undang Nomor 3 Tahun 2006, dan perubahan kedua dengan Undang-undang Nomor 50 Tahun 2009".

Kebebasan berakad/kontrak (mabda Hurriyyah at Ta'aqud) diakui dalam hukum Islam. Kebebasan berakad merupakan prinsip hukum yang menyatakan bahwa setiap orang dapat membuat akad jenis apapun tanpa terikat pada nama-nama yang telah ditentukan dalam undang-undang syariah dan memasukan klausul apa saja ke dalam akad yang dibuatnya itu sesuai dengan kepentingannya sejauh tidak berakibat makan harta bersama dengan jalan batil.

Aturan dalam al-Quran dan Sunnah Nabi Saw sebagai otoritas utama sumber hukum Islam serta kaidah-kaidah hukum Islam menunjukan bahwa hukum Islam menganut asas kebebasan berakad. Asas kebebasan ini merupakan konkretisasi labih jauh dari spesifikasi yang lebih tegas lagi terhadap asas ibahah dalam bermuammalah. Dalam Firman
Allah (QS. 5:1):

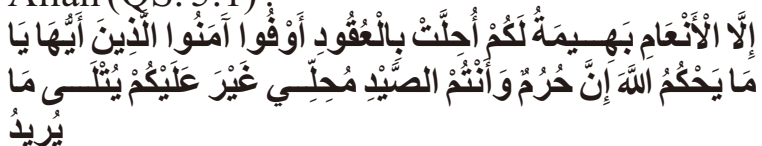

Artinya: Wahai orang-orang yang beriman, penuhilah akad-akad (perjanjianperjanjian)......

Ayat ini memerintahkan kaum mu'minin untuk memenuhi akad-akad. Menurut kaidah ushul fikih (metodologi penemuan hukum Islam), perintah dalam ayat ini (kata: aufu) menunjukan wajib. Artinya memenuhi akad itu hukumnya wajib. Dalam ayat ini "akad" disebutkan dalam bentuk jamak yang diberi kata sandang "al" (alaqadàal-uqud). Menurut kaidah usul fikih, jamak yang diberi kata sandang "al" menunjukan makna umum. Dengan demikian, dari ayat tersebut dapat disimpulkan bahwa orang dapat membuat akad apa saja baik yang bernama maupun yang tidak bernama dan akad-akad itu wajib dipenuhi.

Di samping itu, ada kaidah hukum Islam yang berbunyi, "pada asasnya akad itu adalah kesepakatan para pihak dan akibat hukumnya adalah adanya apa yang mereka tetapkan atas diri mereka melalui janji" Kaidah ini menunjukan adanya kebebasan berakad karena perjanjian itu dinyatakan sebagai berdasarkan kata sepakat para pihak dan akibat hukumnya adalah apa yang mereka tetapkan melalui janji.

Namun, kebebasan membuat akad dalam Islam bukannya tidak terbatas. Kebebasan tersebut tidak boleh menimbulkan ketidakadilan bagi pihak lain. Dalam QS.4:29 Allah berfirman :

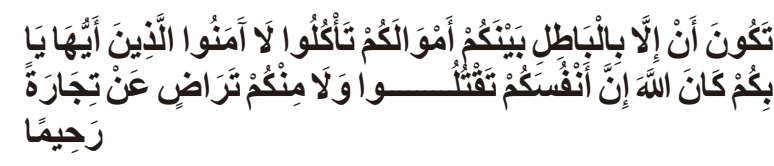

Artinya: Wahai orang-orang yang beriman, janganlah kamu makan harta sesamamu dengan jalan batil, kecuali (jika makan harta sesama itu dilakukan) dengan cara tukarmenukar berdasarkan perizinan timbal balik (kata sepakat) di antara kamu.

Yang dimaksud dengan "makan harta bersama dengan cara batil" adalah makan harta orang lain dengan cara yang tidak dibenarkan dan tidak sah menurut hukum 
syari'ah, baik yang dilarang secara langsung di dalam Al-Qura'an maupun berdasarkan ijtihad atas nas. Secara umum, dapat dikatakan makan harta dengan jalan batil adalah bertentangan dengan keteriban umum dan kesusilaan. Hanya saja, ketertiban dan kesusilaan dalam hukum Islam lebih luas cakupannya, karena mencakup larangan riba, garar dan syarat peserta akad yang fasid.

Hal ini apabila ditarik kembali pada kasus Hibah dalam penelitian ini, sesuai dengan pernyataan Hakim pada tingkat Kasasi yang mengatakan, " Menimbang bahwa Pasal 210 ayat (1) Kompilasi Hukum Islam menegaskan: Orang yang telah berumur 21 tahun, berakal sehat dan tanpa paksaan dapat menghibahkan sebanyakbanyaknya sepertiga dari harta kekayaannya kepada orang lain atau lembaga di hadapan dua orang saksi untuk dimiliki. Para Tergugat tidak membantah secara tegas bahwa obyek sengketa merupakan satu-satunya harta yang dimiliki para Penggugat, maka berdasarkan fakta hukum tersebut dan Akta Hibah ternyata para Penggugat memberi hibah kepada Tergugat I melebihi dari sepertiga harta kekayaannya, sehingga luas obyek sengketa yang dihibahkan bertentangan dengan hukum, oleh karena itu Akta Notaris No. 162/Klj/11/1999 tertanggal 11 Nopember 1999 yang dibuat oleh Notaris Malang Tri Sukmawati Handayani, S.H. dinyatakan cacat hukum dan tidak mempunyai kekuatan hukum".

"Menimbang bahwa Pasal 212 KHI menyatakan: Hibah tidak dapat ditarik kembali kecuali hibah orang tua pada anakanya, oleh karena itu tuntutan para Penggugat/ Pemohon Kasasi agar hibah sebagaimana tertuang dalam Akta Hibah No. 162/Klj/11/1999 tertanggal 11 Nopember 1999 di hadapan Notaris Malang Tri Sukmawati Handayani, S.H. dinyatakan cacat hukum dan dibatalkan adalaha tuntutan yang mempunyai landasan hukum".

Hal ini membuktikan bahwa putusan Hakim Mahkamah Agung pada tingkat Kasasi dan Peninjauan Kembali adalah tepat dan sesuai dengan aturan KUHPerdata sekaligus syari'at Islam. Sedangkan telah sangat jelas bahwa putusan Hakim pada tingkat pertama dan kedua terjadi sebuah kesalahan karena tidak sesuai dengan asas dan ideologi hukum.

\section{Keabsahan Akata Hibah Nomor 162/Klj/11/1999 Apabila Ditinjau dari Sudut Pandang Kompilasi Hukum Islam}

Syari'at Islam merupakan aturan hukum yang ditetapkan Allah untuk kemaslahatan umat manusia. Hukum atau peraturan dalam menjalankan dan mengamalkan agama Allah termasuk syari'at Islam. peraturan yang telah ditetapkan Allah kepada manusia, baik hubungannya terhadap Allah, maupun hubungan terhadap sesama manusia, alam dan kehidupan .

Hukum secara umum belum mutlak dinamakan Syari'at Islam dalam era modern. Sebab hukum yang bersumber dari Allah (seperti Syari'at Islam) dinamakan hukum samawi, sedangkan hukum yang dibuat oleh manusia disebut hukum wadh'i. Syari'at Islam sebagai hukum samawi berlaku mutlak sedangkan hukum wadh'i sifatnya berlaku relatif hanya berdasarkan kepada kepentingan dan kebutuhan manusia dalam masa-masa tertentu.

Tentunya sebagai seorang muslim tidak dapat mengabaikan aturan atau syari'at Islam dalam setiap tingkahlaku yang dilakukan, terutamaa dalam melakukan suatu perjanjian. Agama Islam memiliki cara pandang yang berbeda dalam mengatur persoalan hibah.

Dalam Al-Qur'an, penggunaan kata hibah digunakan dalam konteks pemberian anugerah Allah SWT kepada utusan-utusanNya, doa-doa yang dipanjatkan oleh hambahamba-Nya, terutama para nabi, dan menjelaskan sifat Allah Yang Maha Memberi Karunia. Namun ayat ini dapat digunakan petunjuk dan anjuran secara umum, agar seseorang memberikan sebagian rezekinya kepada orang lain. Misalnya, QS. Al-Baqarah ayat 262, dimana terjemahannya (Ahmad Rofiq, 1995).

Jumhur fuqaha berpegang bahwa ijma' (kesepakatan) telah terjadi tentang yang diperbolehkan dalam Islam terhadap seseorang dalam keadaan sehatnya memberikan seluruh hartanya kepada orang asing sama sekali di luar anak-anaknya. Jika pemberian seperti ini dapat terjadi untuk 
orang asing, maka terlebih lagi terhadap anak.

Alasan mereka adalah hadits Abu Bakar yang terkenal, bahwa ia memberi 'Aisyah pecahan-pecahan seberat 20 wasaq dari harta hutan. Pada saat menjelang wafatnya, Abu Bakar berkata: "Demi Allah, wahai anakku, tidak seorangpun yang kekayannya lebih menyenangkan aku sesudah aku selain daripada engkau. Dan tidak ada yang lebih mulia bagiku kefakirannya selain daripada engkau. Sesungguhnya aku dahulu memberimu pecahan (emas) 20 wasaq. Maka jika engkau memecah-mecah dan memilikinya, maka itu adalah bagimu. Hanya saja, harta itu sekarang menjadi harta waris" (Ibnu Rusyd,1990).

Mereka berpendapat bahwa maksud hadits tersebut adalah nadb (sunnah). Yang jelas al-Qur'an dan hadits banyak sekali menggunakan istilah yang konotasinya menganjurkan agar manusia yang telah dikarunia rezeki itu mengeluarkan sebagiannya kepada orang lain. Kendati istilah-istilah tersebut memiliki ciri-ciri khas yang berbeda, kesamaannya adalah bahwa manusia diperintahkan untuk mengeluarkan sebagian hartanya.

Menurut jumhur ulama rukun hibah ada empat:

a. Wahib (Pemberi) Wahib adalah pemberi hibah, yang menghibahkan barang miliknya kepada orang lain.

b. Mauhublah (Penerima), Penerima hibah adalah seluruh manusia dalam arti orang yang menerima hibah.

c. Mauhub Mauhub adalah barang yang di hibahkan.

d. Shighat (Ijab dan Qabul) Shighat hibbah adalah segala sesuatu yang dapat dikatakan ijab dan qabul (Sayyid Sabiq, 1987).

Sedangkan syarat-syarat hibah yaitu Hibah menghendaki adanya penghibah, orang yang diberi hibah, dan sesuatu yang dihibahkan.

Disyaratkan bagi penghibah syarat-syarat sebagai berikut:

a. Penghibah memiliki sesuatu untuk dihibahkan

b. Penghibah bukan orang yang dibatasi haknya karena suatu alasan.

c. Penghibah itu orang dewasa, sebab anak- anak kurang kemampuannya.

d. Penghibah itu tidak dipaksa, sebab hibah itu akad yang mempersyaratkan keridhaan dalam keabsahannya.

Disyaratkan bagi orang yang diberi hibah yaitu orang yang diberi hibah harus benarbenar ada waktu diberi hibah. Bila tidak benar-benar ada, atau diperkirakan adanya, misalnya dalam bentuk janin, maka hibah tidak sah. Apabila orang yang diberi hibah itu ada di waktu pemberian hibah, akan tetapi dia masih atau gila, maka hibah itu diambil oleh walinya, pemeliharaannya atau orang mendidiknya sekalipun dia orang asing (R. Subejti,1995).

Selanjutnya syarat-syarat bagi yang dihibahkan, yaitu (C. S. T. Kansil,2002):

a. Benar-benar ada;

b. Harta yang bernilai;

c. Dapat dimiliki zatnya, yakni bahwa yang dihibahkan itu adalah apa yang bisa dimiliki, diterima peredarannya, dan pemilikannya dapat berpindah tangan. Maka tidak sah menghibahkan air di sungai, ikan di laut, burung di udara, masjid-masjid atau pesantrenpesantren;

d. Tidak berhubungan dengan tempat pemilik hibah, seperti menghibahkan tanaman, pohon, atau bangunan tanpa tanahnya;

e. Dikhususkan, yakni yang dihibahkan itu bukan untuk umum, sebab pemegangan dengan tangan itu tidak sah kecuali bila ditentukaan (dikhususkan) seperti halnya jaminan (Sayyid Sabiq, 1987).

Berdasarkan pandangan Islam atas pemahaman serta syarat dari penghibah dan pihak yang diberi hibah apabila dikaitkan dengan Akta Hibah Nomor 162/Klj/11/1999, maka dalam Akta Hibah tersebut yang berperan sebagai Pemberi Hibah adalah $\mathrm{H}$. Achmad Jakoen Tjokrohadin bin Achmad Tohir beserta istri kepada pihak Penerima Hibah yang berposisi anak kandung dari Pemberi Hibah yaitu Dra. Ani Hadi Setyowati alias Ani Indra Sudibyo binti H. Achmad Jakoen.

Bahwasannya Akta Hibah Nomor $162 / \mathrm{Klj} / 11 / 1999$ telah memenuhi syarat awal dari proses hibah, yaitu terpenuhinya unsur adanya pihak-pihak mulai dari Pemberi 
Hibah dan Penerima. Selanjutnya, dilihat dari syarat mengenai obyek yang di hibahkan, yaitu yang dalam perkara ini merupakan tanah dan bangunan seluas $983 \mathrm{~m} 2 \mathrm{di} \mathrm{J} 1$. Diponegoro No. 02 RT. 01, RW 05, juga telah terpenuhi karena obyek tersebut telah ada pada saat hibah berlangsung dan diberikan pada pihak yang benar-benar ada pada saat hibah tersebut berlangsung.

Namun tidak berhenti pada atauran dasar tersebut karena apabila di tinjau dari atauran dalam Pasal 210 ayat (1) Kompilasi Hukum Islam yang menegaskan " Orang yang telah berumur 21 tahun, berakal sehat dan tanpa paksaan dapat menghibahkan sebanyakbanyaknya 1/3 harta bendanya kepada orang lain atau lembaga di hadapan dua orang saksi untuk dimiliki" tersebut ada hal inti yang terabaikan dalam Akta Hibah Nomor 162/Klj/11/1999.

Hal tersebut adalah mengenai porsi obyek hibah yang diberikan kepada salah satu anak dari 8 (delapan) bersaudara tersebut, obyek hibah tersebut diketahui merupakan satu-satunya harta dari Pemberi Hibah, maka berdasarkan fakya hukum tersebut maka Akta Hibah tersebut cacat secara hukum karena tidak sesuai dengan aturan dalam Kompilasi Hukum Islam.

Terdapat dua hal yang hendak dicapai oleh hibah yakni, Pertama, dengan beri memberi akan menimbulkan suasana akrab dan kasih sayang antara sesama manusia. Sedangkan mempererat hubungan silaturrahmi itu termasuk ajaran dasar agama Islam. Kedua, yang dituju oleh anjuran hibah adalah terbentuknya kerjasama dalam berbuat baik, baik dalam menanggulangi kesulitan saudaranya, maupun dalam membangun lembaga-lembaga sosial (Satria Effendi M. Zein, 2004).

Berlanjut pada aturan dalam Kompilasi Hukum Islam, yaitu dalam Pasal 212 Kompilasi Hukum Islam yang berbunyi “ Hibah tidak dapat ditarik kembali, kecuali hibah orang tua kepada anaknya". Berdasarkan aturan Kompilasi Hukum Islam tersebut sangat jelas dikatakan bahwa hibah yang berasal dari orang tua kepada anaknya dapat dengan sah untuk ditarik kembali.

Apabila dikaitkan pada Akta Hibah Nomor $162 / \mathrm{Klj} / 11 / 1999$, mengingat tentang perihal utama yaitu tujuan dari dilakukannya Hibah adalah untuk mempererat tali persaudaraan dan sebagai bentuk kasih sayang maka hasil yang diwujudkan oleh Akta Hibah ini sangatlah bertentangan dan tidak sejalan dengan tujuan hakiki sebuah Hibah.

Selain itu mengingat bahwa dalam kasus ini pihak Pemberi Hibah merupakan orang tua kandung dari pihak Penerima Hibah maka sangat diperbolehkan dan sah secara Hukum Islam berdasarkan Pasal 212 Kompilasi Hukum Islam apabila pihak Pemberi Hibah merasa ingin menarik Hibah yang telah diberikan dan seharusnya pihak Penerima Hibah dapat berlapang dada dan ikhlas dalam perihal penarikan hibah tersebut.

Hibah Menurut aturan hukum Islam dapat dilakukan baik secara tertulis maupun lisan, bahkan telah ditetapkan dalam Hukum Islam, pemberian yang berupa harta tidak bergerak dapat dilakukan dengan lisan tanpa mempergunakan suatu dokumen tertulis. Namun jika ditemukan bukti-bukti yang cukup tentang terjadinya peralihan hak milik, maka pemberian tersebut dapat dinyatakan secara tertulis. Jika pemberian tersebut dilakukan dalam bentuk tertulis, bentuk tersebut terdapat dua macam yaitu (Ahmad Rofiq,1995):

1. Bentuk tertulis yang tidak perlu didaftarkan, jika isinya hanya menyatakan bahwa telah terjadinya pemberian;

2. Bentuk tertulis yang perlu didaftarkan, jika surat tersebut merupakan suatu alat dari penyerahan pemberian itu sendiri. Artinya, apabila penyerahan dan pernyataan terhadap benda yang bersangkutan kemudian disusul oleh dokumen resmi tentang pemberian, maka yang demikian itulah yang harus didaftarkan.

Islam merupakan agama yang tidak ingin menyusahkan umatnya, namun Islam juga meyukai kemaslahatan bagi setiap umatnya. Kemaslahatan di sisni yaitu apabila ada upaya yang dapat memberi manfaat lebih maka Islam menganjurkannya. Termasuk dalam persoalan Akta Notariil.

Seperti yang telah diketahui bahwa salah satu kegunaan dari sebuah Akta Notariil yaitu 
merupakan sebuah bukti otentik atau sebuah bukti yang memiliki kekuatan hukum, maka dari itu Islam tidak ada larangan apabila umatNya hendak melakukan hibah dengan cara Akta Notariil demi kemaslahatan bersama atau demi suatu bukti pertanggungjawaban apabila dikemudian hari terjadi sesuatu yang tidak dikehendaki oleh para pihak.

\section{Simpulan}

Bahwa telah terjadi suatu kesalahan dalam Putusan pada tingkat pertama dan kedua, karena tidak sesuai dengan aturan dalam Perundang-undangan dan hal ini dikuatkan dengan putusan Hakim pada tingkat Mahkamah Agung (MA) dengan amar Hakim pada tingkat Kasasi dimana Hakim mengatakan bahwa " Pasal 1338 tersebut tidak dapat diterapkan pada Pasal 5 akta hibah yang dibuat antara para Penggugat dengan Tergugat I karena klausul Pasal 5 akta hibah tersebut bertentangan dengan Pasal 49 Undang-undang Nomor 7 Tahun 1989 sebagaimana yang telah diubah dengan Undang-undang Nomor 3 Tahun 2006, dan perubahan kedua dengan Undang-undang Nomor 50 Tahun 2009".

Terlepas dari itu Islam menganggap sah hibah baik secara lisan maupun tertulis, sepanjang segala syarat terpenuhi. Maka apabila dipantau berdasarkan paparan di atas maka ada beberapa hal pokok yang membuat Akta Hibah Nomor 162/Klj/11/1999 tersebut cacat secara hukum Islam. Hal-hal tersebut yaitu mengenai porsi dari obyek hibah yang diberikan telah melebihi dari aturan seharusnya dalam Kompilasi Hukum Islam, yaitu $1 / 3$ dari harta yang dimiliki oleh pihak Pemberi Hibah.

Lalu yang kedua yaitu, bahwa bukanlah sesuatu hal yang salah dan melanggar aturan apabila pihak Pemberi Hibah hendak menarik kembali hibah yang diberikan kepada pihak Penerima Hibah, karena berdasarkan Pasal 212 Kompilasi Hukum Islam dibenarkan apabila hibah yang berasal dari orang tua kepada anaknya dapat diambil atau ditarik kembali.

Apabila dilihat dari sudut pandang Hukum Islam dan aturan dalam Kompilasi Hukum Islam mengenai perkara Hibah, maka dapat dikatakan bahwa keabsahan dari Akta Hibah Nomir 162/K1j/11/1999 masih diragukan. Akta Hibah tersebut tidak memenuhi beberapa unsur penting atau dasar syarat sahnya sebuah hibah.

\section{DAFTAR PUSTAKA}

\section{Buku:}

Al-Jaziry, Abdurahman, 1987, Kitab Fiqhi 'ala al-Mazhabai al Arba'ah, Dar AlFikr, Maktabat At-Tijariyah, Beirut.

Arikunto, Suharsimi, 2002, Prosedur Penelitian: Suatu Pendekatan Praktek, Rieneka Cipta, Jakarta.

Bungin, Burhan, 2007, Metodologi Penelitian Kualitatif : Aktualisasi MetodologiKe arah Ragam Varian Kontemporer, PT. RajaGrafindo Persada, Jakarta.

Fayzee, A. A, 1961, Pokok-Poko Hukum Islam II, Tintamas, Jakarta.

Harsono, Boedi, 2003, Hukum Agraria Indonesia (Sejarah Pembentukan Undang-undang Pokok Agraria,Isi, dan Pelaksanaannya), Djambatan, Jakarta.

Hidjaz, Kamal, 2010 , Efektivitas Penyelenggaraan Kewenangan Dalam Sistem Pemerintahan Daerah Di Indonesia, Pustaka Refleksi, Makasar.

HR, Ridwan, 2013, Hukum Administrasi Negara, PT Raja Grafindo Persada, Jakarta.

Ibrahim, Jhonny, 2006, Teori dan Metodologi $P$ e n e litian Hukum Normatif,Bayumedia Publishing, Malang.

Kansil, C.S.T, 2002, Pengantar Ilmu Hukum Dan Tata Hukum Indonesia, Balai Pustaka, Jakarta.

Marzuki, Peter Mahmud, 2005, Penelitian Hukum, Kencana Prenada Media Group, Jakarta.

Muhammad, Abdulkadir, 2004, Hukum dan Penelitian Hukum, PT. Citra Aditya Bakti, Bandung.

Munawwir, Ahmad Warson, 1997, Kamus AlMunawwir, Pustaka Progressif, 
Surabaya.

Pasaribu, Chairuman, Lubis, Suhrawadi K, 1994, Hukum Perjanjian Dalam Islam, Sinar Grafika, Jakarta.

Rofiq, Ahmad, Hukum Islam Di Indonesia, 1995, PT. Raja Grafindo Persada, Jakarta.

Sabiq, Sayyid, 1987, Fikih Sunnah 14, Terj: Mudzakir, PTAl Ma'arif, Bandung.

Subejti, R, 1995, Aneka Perjanjian, Citra Aditya Bakti, Bandung.

Subekti, R, Tjitrosudibio,R, 1979, Kitab Undang-Undang Hukum Perdata, Pradnya Paramita, Jakarta.

Soekanto, Soerjono, Pokok-Pokok Sosiologi Hukum, 2002, Raja Grafindo Persada, Jakarta.

Soekanto, Soerjono, Mamudji, Sri, 2006, Penelitian Hukum Normatif Tujuan Singkat, Rajawali Pers, Jakarta.

Tutik, Titik Triwulan, 2006, Pengantar iLmu Hukum, Prestasi Pustakaraya: Jakarta.

\section{Artikel dari Jurnal Ilmiah}

Saifullah, 2004, Konsep Dasar Metode Penelitian Dalam Proposal Skripsi, Hand out, Fakultas Syariah UIN Malang.

\section{Peraturan Perundang-undangan}

Kitab Undang-undang Hukum Perdata (KUHPerdata)

Kompilasi Hukum Islam (KHI)

Undang-Undang Nomor: 50 Tahun 2009 tentang Peradilan Agama 